\title{
Research on the Relationship between Levels of Diversification and Enterprise Performance of Real Estate Listed Companies
}

\author{
Jindi Yang \\ Beijing Normal University \\ School of Government \\ Beijing China \\ 201821260024@mail.bnu.edu.cn
}

\author{
Shilin Li \\ Beijing Normal University \\ School of Government \\ Beijing China \\ 201611260226@mail.bnu.edu.cn
}

\author{
Hongping Lian* \\ Beijing Normal University \\ School of Government \\ Beijing China \\ *hplian@bnu.edu.cn
}

\begin{abstract}
This empirical study selects listed companies in the real estate industry as the research object, employs its 2012-2016 information to establish non-balanced panel data, investigates the relation between the levels of company's diversification and enterprise performance and concludes that the level of diversification of real estate listed companies is negatively correlated with enterprise performance. Specifically, the level of diversification of single-business, dominant-business, and low-degree unrelated business has no significant relation with enterprise performance. Highly unrelated diversification is significantly negatively correlated with enterprise performance. After adding the quadratic term of the indicator of the independent variable, this study indicates that, under certain conditions, the increase in level of diversification can help improving enterprise performance. Therefore, real estate listed companies should pay more attention to related industries when implementing the diversification strategy, and controlling the degree of diversification within a certain range.
\end{abstract}

Keywords-Real estate company; Level of Diversification; Enterprise performance

\section{INTRODUCTION}

The real estate industry is related to the people's livelihood and many related industries. It is the most important pillar industry of China's national economy. According to the "Government Working Report" over the years, it can be seen that stabilizing housing consumption, reducing the number of unsold homes, renovation of shanty towns, housing for living in, curbing housing prices, and improving real estate tax legislation all show the government's determination to strengthen the regulation of the real estate industry continuously. In 2018, the market value of the real estate sector evaporated by about 500 billion yuan, and the market-to-book ratio hit a five-year low. Among the TOP3 housing enterprises, HengDa invested in new energy vehicles across the boundary. BiGuiyuan established the modern agricultural company and the robot company. WanKe immediately positioned itself as "urban and rural construction and living service providers." In addition, nearly 20 real estate companies removed the word "real estate" by renaming, which means the adjustment and change of the company's development strategy. From this point of view, whether it is forced by the situation or the needs of enterprise development, diversification has become an important strategic choice for the development of real estate enterprises.

In this context, this study selects listed companies in the real estate industry as the research object, employs its 2012-2016 information to establish non-balanced panel data, and analyzes the relationship between diversification and enterprise performance. As the SFC's annual industry classification adjusts every year, the establishment of non-balanced panel data for research is more suitable for the actual situation.

\section{RELATED LITERATURE}

\section{A. Aspects of diversification}

International researches on diversification focus mainly on diversified categories, the impact of diversification on corporate performance, the value of diversification strategies, the relationship between diversification strategies and core competencies, the factors affecting diversification strategies and the measurement of diversity degree, etc.

Anoff (1957) and Rumelt (1974) used strategic classification method to measure the degree of diversification ${ }^{[1][2]}$; Gort M (1962) firstly used the metrology to focus on the concentration of business operations ${ }^{[3]}$; the current indicators for measuring the degree of diversification are as follows:

Number of business units: The number of business units is only measured as "quantity" and the results are not specific. 
SIC coding system: The SIC code consists of four digits, the first two representing the industry and the last two representing the specific business unit in the industry.

Herfindahl index and entropy index: Compared to the number of business units and SIC coding, the Herfindahl index and the entropy index take the imbalance in the number and distribution of firms in different industries/businesses into account.

\section{B. Aspects of enterprise performance}

Most scholars basically divide corporate performance into profitability, shareholder profitability and development capability. The main measurement indicators include total return on assets, return on net assets and earnings per share, sales profit margin, main business growth rate, Tobin $\mathrm{Q}$ value, EVA, balance score card and sustainable development rate. Tobin's Q value was first proposed by James Tobin. Wernerfelt and Montgomery (1988) used the Tobin Q value as an indicator to measure firm performance for the first time ${ }^{[4]}$. Comment and Jarrell (1995) measured the changes in corporate excess returns before and after the implementation of the diversification strategy ${ }^{[5]}$. The excess value method was first adopted by Berger and Ofek (1995) ${ }^{[6]}$.

\section{Aspects of relationship between levels of diversification and enterprise' performance}

There are two main opinions on the relationship between the level of diversification and enterprise 'performance at home and abroad.

One opinion believed that there is a positive relationship between diversification and corporate performance in terms of risk, taxation, and capital circulation. Lewellen (1971) believed that the company's diversification strategy had advantages in reducing corporate risk and taxation ${ }^{[7]}$; Myers and Majluf (1984) believed that company had sufficient funds to invest in good projects under diversification strategy ${ }^{[8]}$; Zhu Jiang (1999) studied more than 100 companies, and found that diversification reduced the risk of the company's operation ${ }^{[9]}$; Cheng Yong and Xu Kangning (2006) based on the process of research on "optimal diversification level" and found that increasing the diversification of enterprises wound reduce business risks ${ }^{[10]}$.

Another opinion believed that the company's diversification strategy was not conducive to the improvement of corporate performance in terms of repeated investment and discount effect. Berger and Ofek (1995) studied more than 3,000 companies and found that companies implementing diversification strategies were more prone to over-investment and repetitive investment, which led to a decline in corporate performance $^{[6]}$; Qin Bin and Xiao Kun (2013) studied all listed companies that issued A shares in Shenzhen and Shanghai before 2003 and found diversification strategy had a discount effect on corporate value ${ }^{[11]}$.

\section{RESEARCH HYPOTHESIS}

Principal-agent theory believes that diversification gives company managers greater power to diversify the risk of individual portfolios and damages the rights and interests of company owners. The "information asymmetry theory" believes that diversification inevitably makes the company set up multiple departments responsible for different businesses and a large management system affects efficiency and reduces corporate performance. The effect of discounts is that after the implementation of the diversification strategy, the distribution of resources by enterprises is arbitrary and not conducive to corporate performance. From this point of view, enterprises have a diversified strategy, which is likely to fall into a dilemma of diversification. It makes the business advantage of the original field scattered and can't find a foothold in the new field, which is prone to over-investment, cross-investment and low efficiency problem. Based on the above theories, this paper proposes the following assumption.

H1: The level of diversification of real estate listed companies is negatively correlated with enterprise' performance.

The idea of measuring the degree of diversity with relevant diversification and irrelevant diversification was first proposed by Rumelt (1974) ${ }^{[2]}$. Through analyzing of large American companies, Rumelt found that the core functions of enterprises being limited in resource extension and resource sharing, and implementing non-related pluralism reduced corporate performance; Comment and Jarrell (1995) researched listed companies of NYSE and AMEX between 1978 and 1989 and concluded that the more concentrated the company's operating units, the higher the stock yield ${ }^{[4]}$. In combination with the above scholars' views, the following assumption is made.

H2: Compared with non-related diversification, relevant diversification has a stronger positive correlation with corporate performance.

Grant (1988) believed that the number of business units had a positive impact on corporate performance, but beyond a certain range, it wound have a negative impact on company performance $^{[12]}$; Su Shi, Liu Yulong (2017) divided corporate diversification into industry diversification and product diversification and concluded that product diversification and corporate performance had an inverted "U" relationship ${ }^{\text {[13] }}$. Therefore, this paper proposes the following assumption.

H3: There is an inverted "U" shaped relationship between diversified management of real estate listed companies and corporate performance.

\section{EMPIRICAL RESEARCH}

\section{A. Data Collection and Selection}

This paper selects all real estate listed companies that only issue A shares in Shanghai and Shenzhen stock markets as research samples, taking 2012 to 2016 as sample observation period. These companies belong to the real estate industry in the "Guidelines for the Classification of listed companies " issued by the China Securities Regulatory Commission.

\section{B. Variable description}

This paper selects three indicators: business unit, Herfindahl index and entropy index to measure diversification. The reason is that even though the number of cross-industry operations of the two companies is the same, the proportion of the company's operating income is different. Hence, the degree 
of diversification is different. The more business units, the smaller the Herfindahl index, the larger the entropy index, the higher the company's diversification.

This paper measures corporate performance using profitability and shareholder profitability. Considering the availability of data, this paper chooses the return on total assets, return on equity, and earnings per share as explanatory variables.
In the selection of control variables, seven indicators were preliminary selected: the Equity concentration Herfindahl index (H10), owner's equity growth rate (EQU), controller change (CON), asset turnover (CTUR), company size (Size), company age (Age) and asset-liability ratio (Lev). The correlation analysis showed that correlation coefficients between H10, EQU, CON, CTUR and dependent variable were low (less than 0.15 ) and were not significant, so they were eliminated, and finally retains Size, Age, Lev as control variable.

TABLE I.

VARIABLE DEFINITION TABLE

\begin{tabular}{|c|c|c|c|}
\hline Variable type & Variable name & symbol & Variable definition \\
\hline \multirow[t]{3}{*}{$\begin{array}{c}\begin{array}{c}\text { Independent } \\
\text { variable }\end{array} \\
\end{array}$} & $\begin{array}{l}\text { Number of business } \\
\text { units }\end{array}$ & Unit & Cross-industry number of company operating income \\
\hline & Herfindahl Index & $\mathrm{H}$ & $\begin{array}{l}\text { The sum of square of the proportion of sales revenue of each business unit in the company's operation } \\
\text { to the total sales revenue }\end{array}$ \\
\hline & Entropy index & En & $\begin{array}{l}\qquad E \mathrm{n}=\sum_{i=1}^{n} P_{i} \operatorname{In}\left(1 / P_{i}\right) * 100 \% \\
p_{i} \text { represents the proportion of sales revenue of each business unit in the company's operation to the } \\
\text { total sales revenue }\end{array}$ \\
\hline \multirow[t]{3}{*}{$\begin{array}{c}\text { Dependent } \\
\text { variable }\end{array}$} & Return on total assets & ROA & Return on total assets $=$ net profit $/$ average total assets $\times 100 \%$ \\
\hline & Return on equity & ROE & Return on equity $=$ net profit $/$ average net Assets $\times 100 \%$ \\
\hline & Earnings per share & EPS & Earnings per share $=$ net income for the year $/$ total number of ordinary shares $\times 100 \%$ \\
\hline \multirow[t]{3}{*}{ Control Variable } & Company size & Size & The natural logarithm of the company's total assets \\
\hline & Company age & Age & The time elapsed since the company was founded \\
\hline & Asset-liability ratio & Lev & Total liabilities / shareholders' equity \\
\hline
\end{tabular}

\section{Research model}

In order to examine the relation between diversification and enterprise performance, the theoretical model $\mathrm{I}$ is constructed as follows:

$$
Y=a_{0}+a_{1} X_{i}+a_{2} C_{1}+a_{3} C_{2}+a_{4} C_{3}+u
$$

Among them, $\mathrm{Y}$ is the company's operating performance, measured by the total return on assets, return on net assets and earnings per share. $X_{i}$ represents the degree of diversification of the company. This paper uses the mean value of diversified operating level indicators of listed companies in the real estate industry from 2012 to 2016 to measure. $C_{1}-C_{3}$ is the control variable, it stands for Size, Age, and Lev; $a_{1}-a_{4}$ is the coefficient, the coefficient is positive for positive correlation, and is negative for negative correlation.

In order to examine the relation between various types of listed companies and corporate performance, this paper constructs a theoretical model II as follows:

$$
Y=a_{0}+a_{1} X_{i}+a_{2} C_{1}+a_{3} C_{2}+a_{4} C_{3}+u
$$

Among them, $Y$ is the index for measuring the performance of the enterprise. $X_{i}$ is Herfindahl index which measures the type of the enterprise, $C_{1}-C_{3}$ is the control variable, which represents Size, Age, and Lev. $a_{1}-a_{4}$ is coefficient, the positive coefficient means positive correlation, and the negative coefficient means negative correlation.
In order to verify whether there is a nonlinear relationship between diversification and corporate performance, the theoretical model III is constructed as follows:

$$
Y=a X^{2}+b X+C
$$

Among them, $\mathrm{Y}$ represents the enterprise performance index, $\mathrm{X}$ is the diversification degree measurement index, $\mathrm{a}, \mathrm{b}$ is the coefficient, and $\mathrm{C}$ is the constant term.

\section{DATA ANALYSIS AND CONCLUSION}

The data are all from the WIND database, and is analyzed by Stata software. In addition, in order to avoid the impact of extreme values, this paper has $1 \%$ winsorize processing of enterprise performance indicators and asset-liability ratio.

\section{A. Descriptive analysis}

As can be seen from TABLE II, the average number of operating units of these listed companies is no more than three, the average value of the Herfindahl index is $75 \%$, and the average entropy index is $41.2 \%$. It can be seen that these listed companies have little diversification. 
TABLE II. DESCRIPTIVE ANALYSIS OF EACH VARIABLE INDICATOR

\begin{tabular}{|c|c|c|c|c|c|}
\hline Variable & $\begin{array}{c}\text { Number } \\
\text { of samples }\end{array}$ & Mean & $\begin{array}{c}\text { Std. } \\
\text { Dev. }\end{array}$ & Min & Max \\
\hline ROA & 561 & 0.0286 & 0.0329 & -0.0717 & 0.152 \\
\hline ROE & 561 & 0.0945 & 0.103 & -0.343 & 0.426 \\
\hline EPS & 561 & 0.392 & 0.441 & -0.780 & 1.960 \\
\hline Unit & 561 & 2.934 & 1.605 & 1 & 11 \\
\hline H & 561 & 0.750 & 0.223 & 0.000546 & 1.000 \\
\hline En & 561 & 0.412 & 0.375 & $1.58 \mathrm{e}-05$ & 1.830 \\
\hline Size & 561 & 23.26 & 1.331 & 19.42 & 27.45 \\
\hline Lev & 561 & 0.655 & 0.162 & 0.158 & 0.926 \\
\hline Age & 561 & 21.00 & 4.587 & 9 & 36 \\
\hline
\end{tabular}

This paper refers to Yun Lina (2006) and group companies according to the level of the Herfindahl index, more details as follows:

TABLE III. CLASSIFICATION OF COMPANIES ACCORDING TO THE HERFINDAHL INDEX

\begin{tabular}{|c|c|}
\hline Herfindahl index & Group \\
\hline$>=\mathbf{9 5} \%$ & Single business company \\
\hline $\mathbf{7 0} \%<=\mathbf{H}<\mathbf{9 5} \%$ & Leading business company \\
\hline $\mathbf{5 0 \%}<=\mathbf{H}<\mathbf{7 0} \%$ & Low irrelevant diversified company \\
\hline $\mathbf{H}<\mathbf{5 0} \%$ & Highly irrelevant diversified company \\
\hline
\end{tabular}

After grouping listed companies in the real estate industry according to the above criteria, the number of companies diversified in each category from 2012 to 2016 is as follows:
TABLE IV. NUMBER OF COMPANIES DIVERSIFIED IN EACH CATEGORY IN 2012-2016

\begin{tabular}{|c|c|c|c|c|c|c|}
\hline & $\mathbf{2 0 1 2}$ & $\mathbf{2 0 1 3}$ & $\mathbf{2 0 1 4}$ & $\mathbf{2 0 1 5}$ & $\mathbf{2 0 1 6}$ & total \\
\hline Single business company & 26 & 26 & 24 & 17 & 18 & 111 \\
\hline $\begin{array}{c}\text { Leading business } \\
\text { company }\end{array}$ & 43 & 45 & 47 & 47 & 59 & 241 \\
\hline $\begin{array}{c}\text { low irrelevant business } \\
\text { company }\end{array}$ & 22 & 22 & 22 & 26 & 15 & 107 \\
\hline $\begin{array}{c}\text { Highly irrelevant business } \\
\text { company }\end{array}$ & 22 & 20 & 19 & 19 & 22 & 102 \\
\hline total & 113 & 113 & 112 & 109 & 117 & 561 \\
\hline
\end{tabular}

As can be seen from the TABLE IV, the implementation of diversification strategies is common in these listed companies, but the degree of diversification is generally low.

\section{B. Correlation analysis}

In order to investigate the relation and multicollinearity problem between the independent variable and the dependent variable, this paper analyzes the correlation of variables.

As shown in table $\mathrm{V}$, the three indicators that measure the degree of diversification of the company are relatively high in correlation, which verifies the correctness of the choice of independent variable indicators. There are some correlations between the three indicators of explanatory variables and the three indicators of the explanatory variables, but the correlation coefficients are not high, basically no more than $17 \%$,

TABLE V. CORRELATION ANALYSIS BETWEEN VARIABLES

\begin{tabular}{|c|c|c|c|c|c|c|c|c|c|}
\hline & ROA & ROE & EPS & Unit & H & En & Size & Lev & Age \\
\hline ROA & 1 & & & & & & & & \\
\hline ROE & 0.812 & 1 & & & & & & & \\
\hline EPS & 0.609 & 0.775 & 1 & & & & & & \\
\hline Unit & -0.0760 & -0.0512 & 0.00620 & 1 & & & & & \\
\hline H & 0.112 & 0.169 & 0.136 & -0.504 & 1 & & & & \\
\hline En & -0.0968 & -0.142 & -0.0967 & 0.699 & -0.929 & 1 & & & \\
\hline Size & 0.0516 & 0.324 & 0.533 & 0.155 & 0.137 & -0.0737 & 1 & & \\
\hline Lev & -0.191 & 0.159 & 0.186 & 0.0409 & 0.203 & -0.184 & 0.592 & 1 & \\
\hline Age & 0.108 & 0.0544 & 0.0979 & 0.142 & -0.0952 & 0.107 & 0.0341 & -0.0602 & 1 \\
\hline
\end{tabular}

\section{Regression results and analysis}

TABLE VI. REGRESSION RESULTS OF ENTROPY INDEX AND FIRM PERFORMANCE IN HIGHLY IRRELEVANT DIVERSIFICATION

\begin{tabular}{|c|c|c|c|}
\hline & ROA & ROE & EPS \\
\hline En & $-0.116^{* * *}$ & $-0.339^{* * *}$ & $-0.970^{* * *}$ \\
\hline & $(0.0312)$ & $(0.0863)$ & $(0.320)$ \\
\hline Size & $0.0202^{* *}$ & $0.0701^{* *}$ & $0.255^{* *}$ \\
\hline & $(0.00977)$ & $(0.0271)$ & $(0.100)$ \\
\hline Lev & $-0.192^{* * *}$ & $-0.345^{* *}$ & $-1.015^{*}$ \\
\hline & $(0.0530)$ & $(0.147)$ & $(0.543)$ \\
\hline Age & $-0.00899^{* * *}$ & $-0.0275^{* * *}$ & $-0.0794^{* * *}$ \\
\hline & $(0.00281)$ & $(0.00780)$ & $(0.0289)$ \\
\hline Constant & -0.0148 & -0.401 & -2.279 \\
\hline & $(0.187)$ & $(0.519)$ & $(1.922)$ \\
\hline Observations & 102 & 102 & 102 \\
\hline R-squared & 0.363 & 0.324 & 0.231 \\
\hline & & &
\end{tabular}

\begin{tabular}{|c|c|c|c|}
\hline \multicolumn{4}{|c|}{ Cont. to TABLE VI } \\
\hline Number of code & 38 & 38 & 38 \\
\hline $\mathbf{F ( 4 , 6 0 )}$ & 8.53 & 7.20 & 4.50 \\
\hline Sign. & 0.0000 & 0.0001 & 0.0030 \\
\hline
\end{tabular}

Note: Standard error in parentheses

*** $\mathrm{p}<0.01, * * \mathrm{p}<0.05, * \mathrm{p}<0$.

In this paper, the F-test and the Hausman test are used to select model (the mixed OLS model, the fixed-effect model or the random-effect model.). After testing, it is more suitable to establish a fixed-effect model.

According to the regression analysis of the data, generally, the number of business units does not have a significant impact on corporate performance and the increase of diversification of the enterprise will reduce the business performance. Specifically, the coefficients of the diversification degree of the single-service company, the leading business company and the low irrelevant diversified company do not pass the significance test. While the coefficient of the diversification of 
the enterprise in the highly irrelevant diversification passes the significance test. That is, the diversification does not have significant impacts on business performance in the single business, dominant business and low unrelated diversification, but the highly irrelevant diversification will reduce the business performance of the enterprise significantly (TABLE VI.).

\section{Nonlinear relationship test}

In this paper, the quadratic term of diversification index is added to the full sample model. In the regression result of entropy index to business performance, the coefficient of the quadratic term of entropy index is negative and passes the significance test.

TABLE VII. NONLINEAR RELATIONSHIP BETWEEN ENTROPY INDEX AND FIRM PERFORMANCE

\begin{tabular}{|c|c|c|c|}
\hline & ROA & ROE & EPS \\
\hline En & 0.0116 & 0.0693 & $0.325^{*}$ \\
\hline & $(0.0166)$ & $(0.0514)$ & $(0.166)$ \\
\hline$E n^{2}$ & $-0.0320^{* *}$ & $-0.119 * * *$ & $-0.390 * * *$ \\
\hline & $(0.0137)$ & $(0.0422)$ & $(0.136)$ \\
\hline Size & $0.0139 * * *$ & $0.0521^{* * *}$ & $0.196 * * *$ \\
\hline & $(0.00340)$ & $(0.0105)$ & $(0.0339)$ \\
\hline Lev & $-0.111^{* * *}$ & $-0.183^{* * *}$ & $-0.677 * * *$ \\
\hline & $(0.0167)$ & $(0.0516)$ & $(0.166)$ \\
\hline Age & $-0.00473 * * *$ & $-0.0181^{* * *}$ & $-0.0429 * * *$ \\
\hline Constant & $(0.00102)$ & $(0.00315)$ & $(0.0102)$ \\
\hline & $-0.119 *$ & $-0.608 * * *$ & $-2.842 * * *$ \\
\hline Observations & $(0.0629)$ & $(0.194)$ & $(0.626)$ \\
\hline R-squared & 561 & 561 & 561 \\
\hline Number of code & 0.124 & 0.098 & 0.090 \\
\hline F & 118 & 118 & 118 \\
\hline Sign. & 0.0000 & 0.0000 & 0.0000 \\
\hline
\end{tabular}

Note: Standard error in parentheses

*** $\mathrm{p}<0.01, * * \mathrm{p}<0.05, * \mathrm{p}<0.1$

The results show that the diversified operation of real estate listed companies and corporate performance have a "U"-type relationship. When the diversified operation level is controlled at $18 \%$ or less, the improvement of diversification will help improving corporate performance.

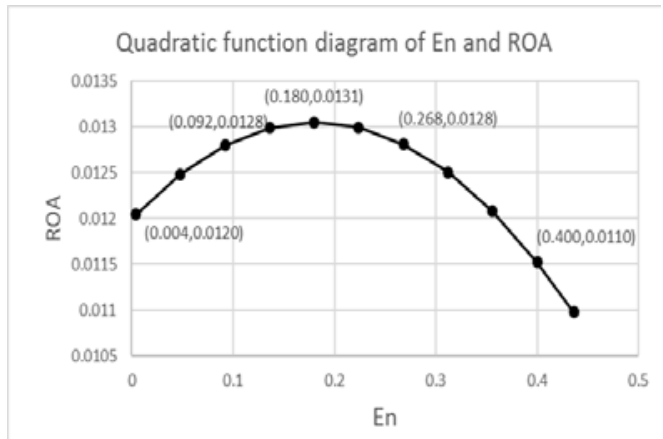

Fig. 1. Relationship between entropy index and total return on assets

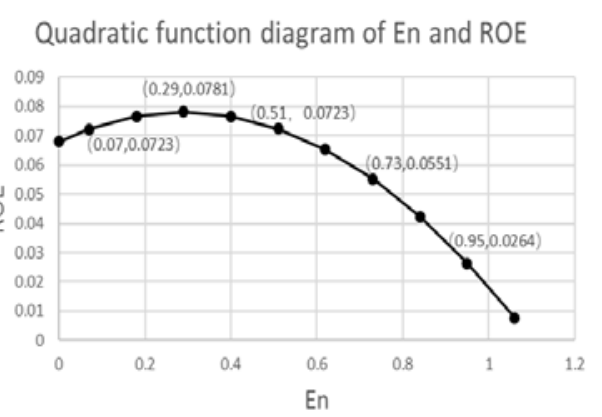

Fig. 2. Relationship between entropy index and return on net assets

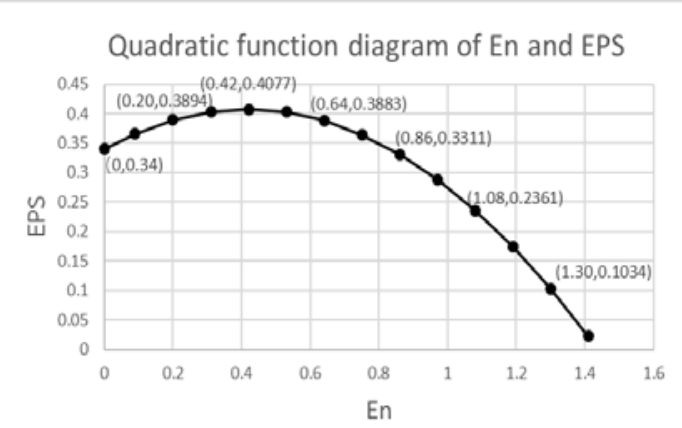

Fig. 3. Entropy index and earnings per share

\section{CONCLUSIONS AND SUGGESTIONS}

After the empirical analysis, all three hypotheses have been verified. When implementing a diversification strategy, real estate listed companies should avoid blind diversification and blind unrelated diversification, pay attention to the company's diversified structure, increase the correlation of the company's internal industry (business) and combine its own actual situation, not blindly expanding the business implement a diversification strategy within the appropriate scope.

\section{REFERENCES}

[1] Ansoff H I. Strategies for diversification[J]. Harvard Business Review, 1957, 33(5):113-124.

[2] Rumelt R P. Strategy, structure, and economic performance[J]. Journal of Behavioral Economics, 1974(75):91-92.

[3] Gort M. Diversification and Integration in American Industry[J]. Nber Books, 1962, 15(15):621.

[4] Wernerfelt B, Montgomery C A. Tobin's q and the Importance of Focus in Firm Performance[J]. American Economic Review, 1988, 78(1):246-250.

[5] Comment R, Jarrell G A. Corporate focus and stock returns 弥, 㶦 [J]. Papers, 1995, 37(1):67-87.

[6] Berger P G, Ofek E. Diversification's effect on firm value[J]. Journal of Financial Economics, 1995, 37(1):39-65.

[7] Lewellen W G. A PURE FINANCIAL RATIONALE FOR THE CONGLOMERATE MERGER[J]. Journal of Finance, 1971, 26(2):521-537.

[8] Myers S C, Majluf N S. Corporate financing and investment decisions

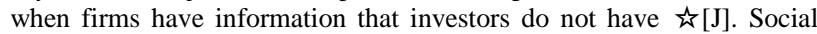
Science Electronic Publishing, 1984, 13(2):187-221.

[9] Zhu, J,Diversification Strategy and Business Performance of listed companies in China [J]. Economic Research, 1999 (11): 54-61. (In Chinese) 
[10] Cheng, Y, Xu, K, Does the Hypothesis of "Optimal Diversification Level" Exist? A Case Study of Chinese listed companies [J].Soft Science of China, 2006 (09): 137-144(In Chinese)

[11] Qin,B, Xiao, K, Empirical Analysis of the Relationship between Diversification and Corporate Performance of Chinese listed companies [J]. Economic Issues, 2013 (1): 82-86. (In Chinese)
[12] Grant, R., A. Jammine, and H. Thomas. Diversity, Diversification, and Profitability Among British Manufacturing Companies, 19721984.Academy of Management Journal, December, 1988: 771-801.

[13] Su,X \& Liu, H, The impact of diversification on corporate performance: the regulatory role of executive stock ownership [J]. Economic issues. (In Chinese) 